\title{
A New Technique for the Fabrication of Interim Obturator
}

\author{
Satya Prakash M.1, Vinoth Kumar Sengottaiyan², Dhanraj M. Ganapathy ${ }^{3}$, Padma Ariga ${ }^{4}$, Ashok V. ${ }^{5}$ \\ 1, 2, 3, 4, 5 Department of Prosthodontics, Saveetha Dental College, Saveetha Institute of Medical and Technical Sciences, \\ Chennai, Tamil Nadu, India.
}

\section{INTRODUCTION}

An obturator is a device that is used to close any unnatural opening intraorally. This is usually a defect in the maxilla such as cleft palate or resected maxilla. There are numerous ways of fabricating the open and closed hollow obturator. All these techniques intend to provide a light weight prosthesis that is readily accepted by the patient. The obturator provides the advantage of easy cleans ability, but accumulation of moisture necessitates frequent cleaning. ${ }^{1}$ Removable lids or the covering of the obturator prosthesis usually reduces this disadvantage. Various methods available for fabrication of hollow bulb obturator either as one piece or by processing in two halves and sealing using autopolymerising resin..$^{2}$ One-piece hollow bulb obturator can be fabricated by filling the hollow portion using materials such as sugar, ${ }^{3}$ salt, polyurethane foam, sponge ${ }^{4}$ and gas injection using argon gas. ${ }^{5}$ Non detachable screw cap can also be used to cover the opening made to pour out the sugar or salt.

A case report of a bilateral maxilla defect in a patient with Paget disease is discussed in this article. Oral recovery after hemi maxillectomy poses numerous technical and clinical challenges. The normal treatment sequence includes the installation during the operation of a surgical obturator; then this obturator is removed 5 - 10 days later, and an interim removable obturator is installed and placed for the remainder of the wound healing period. Finally, when major improvements in tissue configuration are no longer required, the definitive obturator is built and positioned about 3 - 6 months after surgery While necessary, 2 the construction of the interim obturator is a trigger of pain and distress during a period that is, of course, already very exhausting for the patient. ${ }^{3-5}$ The clinician also faces problems with mobile, bleeding and non-scarred tissues, mucinous secretions in the oronasal areas. Different types of obturators and fabrication methods have been proposed for both clinicians and patients to address this concern. . $^{6}$

The most commonly seen intraoral defect is the one affecting the maxilla, through an opening into the nasopharynx. These defects can either be congenital or acquired. These are usually large openings in the palate and the surrounding anatomic structures. Obturators are used to seal these defects to restore proper mastication, speech, deglutition, and aesthetics. This article presents case reports describing a new technique for the fabrication of interim obturator.

The aim of this article is to explain a new method of obturation in which two distinct soft liners are created by an interim obturator, for a 58-year-old male patient who has endured bilateral partial maxillary resection, maintaining a band of mucosa in the soft palate. We have described the construction of an obturator of this sort (Figure 1). 2 weeks after the surgery, in the dental chair and on a single appointment, the interim obturator was built as follows.
Corresponding Author: Dr. Satya Prakash M, Department of Prosthodontics, Saveetha Dental College, Saveetha Institute of Medical and Technical Sciences, Chennai, Tamil Nadu, India.

E-mail: dr.sathyaprakash24@gmail.com

DOI: $10.14260 / j e m d s / 2020 / 809$

How to Cite This Article: Satya Prakash $M$, Sengottaiyan $V$, Ganapathy DM, et al. A new technique for the fabrication of interim obturator. $J$ Evolution Med Dent Sci 2020;9(47):36913693, DOI: 10.14260/jemds/2020/809

Submission 03-08-2020,

Peer Review 06-10-2020,

Acceptance 12-10-2020,

Published 30-11-2020.

Copyright (C) 2020 JEMDS. This is an open access article distributed under Creative Commons Attribution License [Attribution 4.0 International (CC BY 4.0)] 
Impression was made following tray less technique using putty into, making the impression in 3 sections and joining the 3 parts with cyanoacrylate. Light body is used as wash impression to record fine details (Figure 2). Master cast is poured with die stone and all the undercuts are blocked with lab putty (Figure 3). An acrylic plate is made on the cast (Figure 4). $75 \%$ of putty was scraped on the cast, reliningmaterial was used in which adhesive was applied on the acrylic plate, the material was mixed, loaded on the plate and pressed it on the cast (Figure 5). GC Soft liner (Figure 6) was used for other $25 \%$ in which it was loaded on the $1^{\text {st }}$ liner then this is placed in the patients mouth for relining and blocking the openings (Figure 7, 8, 9). Excess was removed and insertion was done.
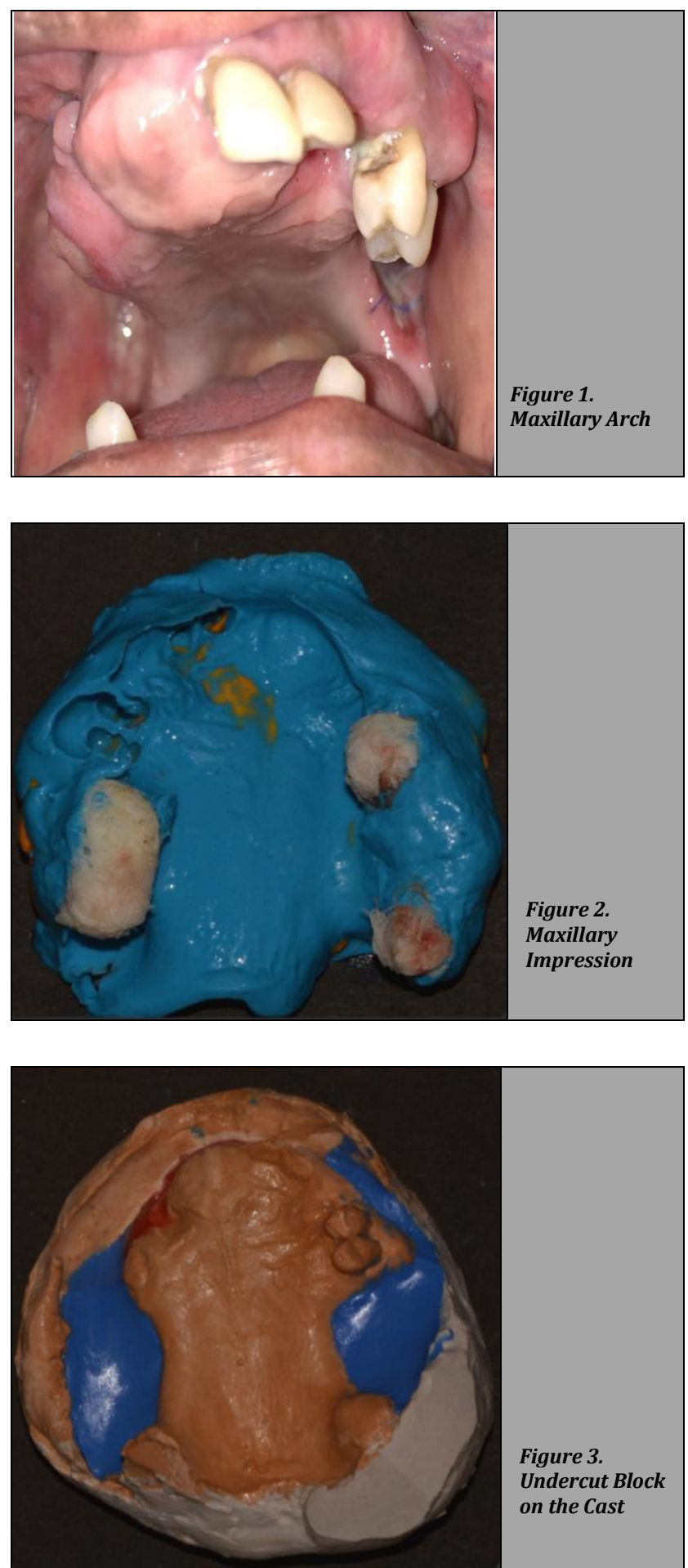
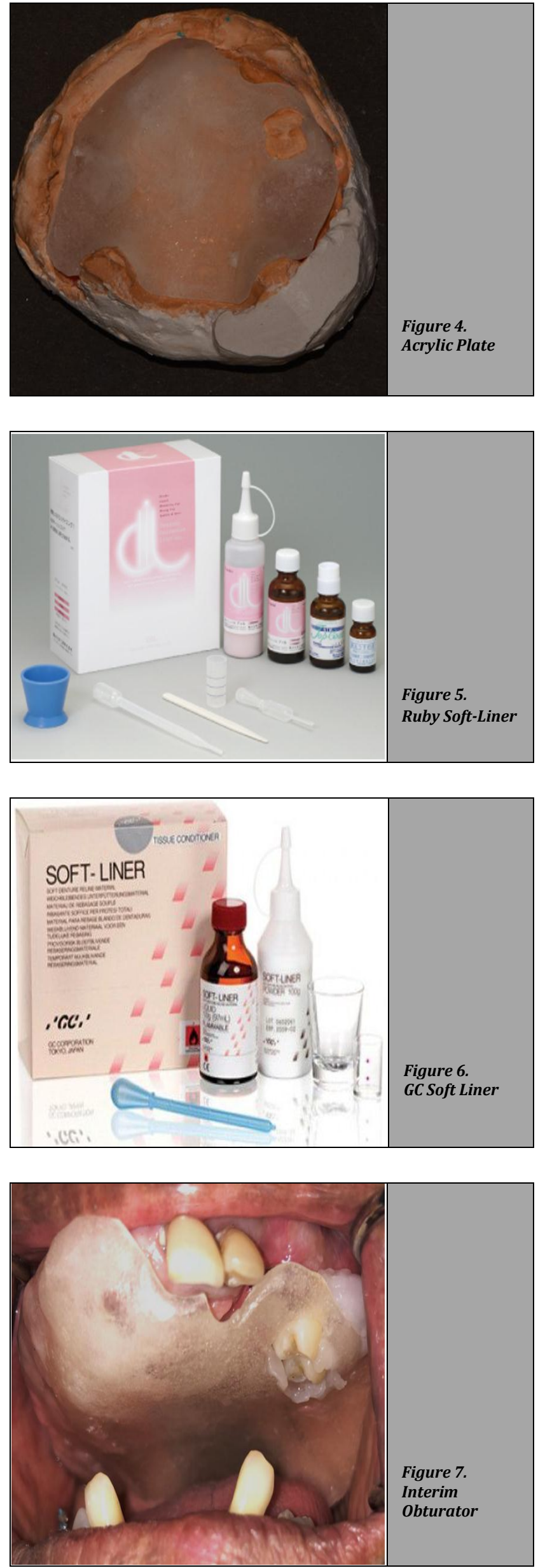

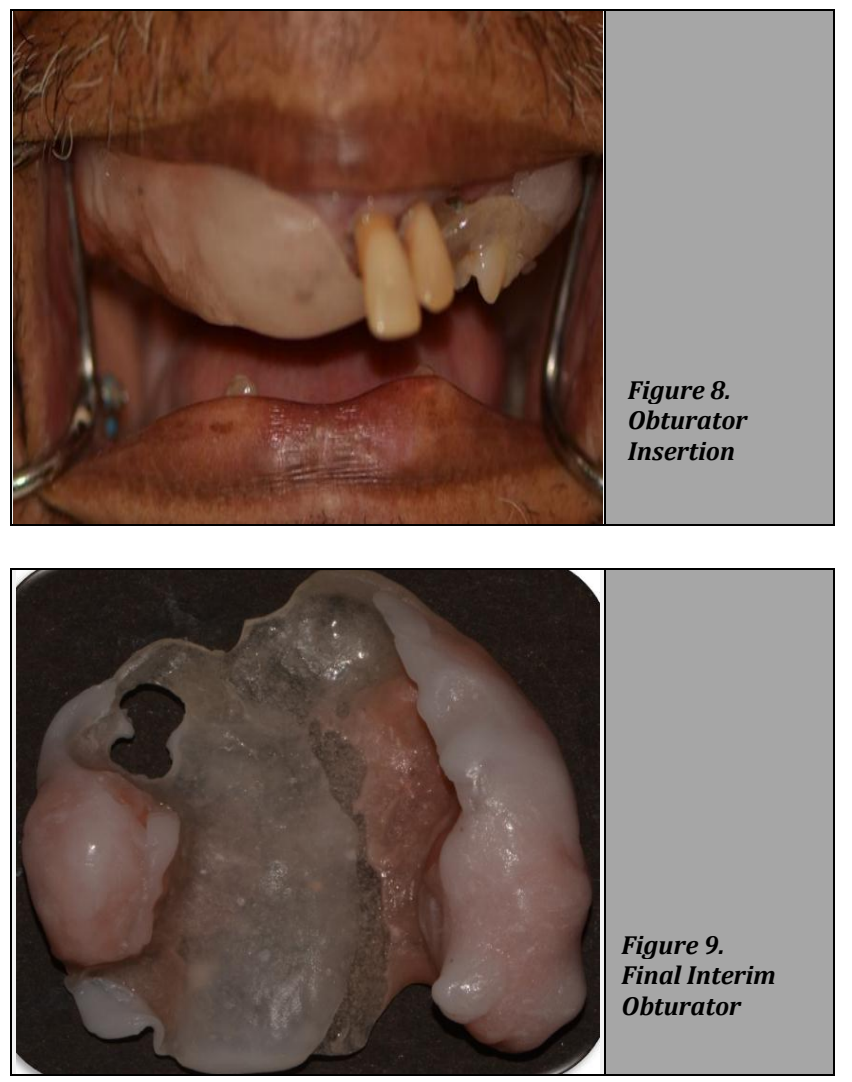

\section{DISCUSSION}

This form of interim obturator favours rapid speech recovery and comfortable swallowing patterns with its less disruptive design to the patient than many alternative procedures. Customary adjustment and modification is required over the 3 - 6 months subsequent to surgery in view of the continuously altering tissue conformation. We reviewed the patient every 7 - 10 days in the present case. There are a range of benefits to the procedure viz. no impressions need to be collected, weight is low since the bulb is hollow and the bulb is filled with a soft reline non damaging to the tissues and encourages good sealing and retention. ${ }^{10}$

The following are major drawbacks to this technique. First, insufficient seal between the bulb and the base of the denture can permit fluid movement into the hollow chamber, where they putrefy and generate appalling odour. Hence, additional concentration must be exercised to ensure proper sealing. Secondly, for longer time periods, soft reliners do not retain optimum properties, but this is unlikely to be a major setback in the current context, as frequent modifications and adjustments of the obturator is required in any case. ${ }^{11}$

Thirdly, the soft reliners binds to the resin very poorly; however, using our system, this issue is less important than if the bulb were made completely of reline material, as in this case, the ratio of weight of reline material to adhesion surface would be much higher. ${ }^{12,13}$ The method mentioned here allows for the construction of short single visit interim obturator in the dental chair, without the need for additional impression making or accessary laboratory services. Soft reline bulb covering implies that it stretches into the defect undercuts when positioned, thereby improving retention and soft reliners are less detrimental to soft tissue healing than hard reliners.

\section{CONCLUSIONS}

The patient was rehabilitated with the interim obturator and was observed for a period of 2 years. The patient expressed satisfaction with the prosthesis and no complications were reported. Obturators are very viable treatment options in rehabilitating patients who underwent surgical maxillary resection.

Financial or other competing interests: None.

Disclosure forms provided by the authors are available with the full text of this article at jemds.com.

\section{REFERENCES}

[1] Chalian VA, Drane JB. Maxillofacial prostheticsmultidisciplinary practice. Baltimore: William and Wilkins 1972.

[2] Mishra MK, Singh RK, Suwal P, et al. Prosthetic rehabilitation of maxillectomy patient with post-surgical obturator: a case report. Journal of College of Medical Sciences-Nepal 2014;10(4):32-6.

[3] McAndrew KS, Rothenberger S, Minsley GE. An innovative investment method for the fabrication of a closed hollow obturator prosthesis. J Prosthet Dent 1998;80(1):129-32.

[4] Matalon V, LaFuente H. A simplified method for making a hollow obturator. J Prosthet Dent 1976;36(5):580-2.

[5] Boucher LJ, Heupel EM. Prosthetic restoration of a maxilla and associated structures. J Prosthet Dent 1966;16:15468.

[6] Iramaneerat W, Seki F, Watanabe A, et al. Innovative gas injection technique for closed-hollow obturator. Int J Prosthodont 2004;17(3):345-9.

[7] Bhat AM. Prosthetic rehabilitation of a completely edentulous patient with palatal insufficiency. Indian J Dent Res 2007;18(1):35-7.

[8] Buzayan MM, Ariffin YT, Yunus N. Closed hollow bulb obturator-one-step fabrication: a clinical report. J Prosthodont 2013;22(7):591-5.

[9] Usman JAM, Ayappan A, Ganapathy D, et al. Oromaxillary prosthetic rehabilitation of a maxillectomy patient using a magnet retained two-piece hollow bulb definitive obturator; a clinical report. Case Rep Dent 2013;2013:190180.

[10] Asher ES, Psillakis JJ, Piro JD, et al. Technique for quick conversion of an obturator into a hollow bulb. J Prosthet Dent 2001;85(4):419-20.

[11] Tanaka Y, Gold HO, Pruzansky S. A simplified technique for fabricating a lightweight obturator. J Prosthet Dent 1977;38(6):638-42.

[12] Nidiffer TJ, Shipmon TH. The hollow bulb obturator for acquired palatal openings. J Prosthet Dent 1957;7(1):12634.

[13] Brown KE. Clinical considerations improving obturator treatment. J Prosthet Dent 1970;24(4):461-6. 